\title{
O registro da cor em requerimentos para concursos de professores
}

\section{Maria Lúcia Rodrigues Müller}

\section{Resumo}

Pretende-se, neste artigo, apresentar dados sobre a origem racial de candidatos a concursos para provimento de vagas de professores adjuntos no magistério público do Rio de Janeiro (antigo Distrito Federal) no período da Primeira República, cruzando o registro da cor nas certidóes de nascimento dos candidatos com outras fontes, assim como discutir o processo de branqueamento do magistério do Distrito Federal, a partir dos debates sobre a suposta inferioridade da população negra brasileira, e o efeito dessas discussóes na racionalização da carreira do magistério. Objetiva-se, também, discorrer sobre as formas de classificação racial dos brasileiros nesse período histórico. A cor da pele, de atributo simplesmente biológico, assume um conteúdo cultural, social e moral em um imenso conjunto de qualificativos inferiorizantes. Esse processo aconteceu, principalmente, com os fenoticamente negros ou de pele mais escura, que não podiam de alguma forma disfarçar sua origem racial.

Palavras-chave: Negros - Brasil - História - República Velha, 1889 - 1930. Discriminação na educação.

Doutora em Educação pela Universidade Federal do Rio de Janeiro, professora do Instituto de Educação e Programa de Pós-Graduação em Educação da Universidade Federal de Mato Grosso, onde coordena o Núcleo de Estudos e Pesquisas sobre Relações Raciais e Educação (Nepre). 


\section{Introdução}

É uma empreitada complexa obter o registro da cor dos indivíduos por meio de documentos de arquivo no período pós-Aboliçâa. A diminuição da diferenciação social entre homens livres, brancos e não brancos, a partir de meados do século XIX, contribuiu para que a cor da pele perdesse, em parte, a qualidade de indicador de posição social, sendo então registrada com menos frequência:

O sumiço do registro da cor consiste num dos processos mais intrigantes e irritantes, ocorridos no século XIX, do ponto de vista do pesquisador. Todos que tentaram trabalhar com a história do negro, após o fim do cativeiro, já se decepcionaram com a quase impossibilidade de alcançá-los, seja trabalhando com processos-crimes e até mesmo com registros civis. (MATTOS, 1998, p. 97).

Contudo, a progressiva adoção pelo Estado brasileiro de processos de qualificação e classificação dos cidadãos, distinguindo-os entre "normais" ou "desviantes", tornou o registro da cor tarefa imprescindível à produção de documentos policiais ou hospitalares, como demonstraram Carrara (1996) e Cunha (2002). Entretanto, ao se buscar informaçóes sobre grupos profissionais que, ainda no início do século XX, auferiam alguma segurança econômica e um mínimo de prestígio social - caso dos professores do Distrito Federal -, verifica-se que aumenta significativamente o grau de dificuldade para se descobrir a origem racial desse grupo ou de parte dele.

Com os resultados da pesquisa aqui apresentados, pretende-se deslindar um mistério - o progressivo desaparecimento desse grupo de docentes -, dado que foi uma decisão das nossas elites, acordada nos gabinetes e náo nas leis, o sepultamento das conquistas de parte da população negra no período pósAbolição. Entre elas, a ocupação de cargos e funçôes no magistério público.

\section{O registro da cor em requerimentos para concursos de professores}

Trata-se de pesquisa documental e iconográfica realizada nos acervos do Arquivo Geral da Cidade do Rio de Janeiro (AGCRJ). Os documentos 
consultados foram: requerimentos para inscrição em concursos públicos para provimento das cadeiras de professores adjuntos; fotografias; livro dos resultados do Censo de 1906.

O requerimento é um documento no qual o candidato solicitava sua inscrição no concurso. A ele era anexado um documento de identificação, como certidáo de nascimento ou outro documento de mesmo teor (certidáo de cartório, atestado de batismo, pública-forma, escritura de perfilhação), atestado de vacinação ou revacinação e memorial. Observa-se que a inscrição de candidatos pertencentes ao sexo masculino era em número reduzido (o ano que apresentou maior número dessas inscrições foi o de 1915).

Graças aos documentos encontrados, constatei que a falta de sobrenome ou a presença de determinados sobrenomes denotava a origem racial dos candidatos, mesmo quando não havia indicaçáo quanto à cor nos registros civis. Consultei, também, o acervo da antiga Escola Normal do Distrito Federal, que se encontra no Instituto de Educação. Ali, descobri livros de atas e de registros de alunos. Contudo, no acervo não foram localizados documentos de identidade de alunos nem de professoras. ${ }^{1}$

Apesar de a Lei do Registro Civil de 1889 determinar o registro da cor na certidão de nascimento, na prática tal determinação não surtiu efeito. A consulta ao setor de iconografia do AGCRJ possibilitou, por meio de fotografias dos docentes, a comprovação da existência de professores negros no Distrito Federal. Ainda que seja difícil precisar a "cor" dos candidatos nesse período, não é tarefa impossível, se transformamos essa dificuldade em um problema histórico. Por esse motivo, foi necessário buscar todos os fiapos de informação e juntá-los em mosaicos de evidências, até que esse verdadeiro quebra-cabeça possibilitasse apresentar um quadro minimamente coerente.

No AGCRJ, foram localizados 1.048 requerimentos para inscrição em concursos públicos para provimento das cadeiras de professores adjuntos. Os requerimentos analisados são referentes aos anos de 1911, 1912, 1913, 1914, 1915, 1916, 1920, 1921, 1928, 1929 e 1931. Nos outros anos desse intervalo de tempo, não localizei requerimentos, provavelmente pela nãorealização de concursos, embora estes fossem obrigatórios por lei. Observei que o item "cor" nas certidóes de nascimento nem sempre era impresso no formulário. Quando constava, seu preenchimento ou náo-preenchimento dependia do escrevente do cartório, que, por sua vez, deveria reproduzir as palavras do declarante. Observa-se, ainda, que o referido item poderia ou 
não constar em certidóes diversas do mesmo cartório. $\mathrm{Na}$ realidade, cada cartório possuía um modelo específico de certidão, ou seja, o formulário não era padronizado como o é atualmente.

Praticamente, todos os requerimentos estavam acompanhados de algum tipo de documento de identificação do candidato, seja certidão de nascimento, seja de batismo, pública-forma ou de perfilhação. A partir de 1920, incluíam-se também atestados de vacinação e revacinação. Nestes, identificou-se um número reduzido de candidatas "não brancas" aos concursos. Contudo, em aproximadamente $60 \%$ deles não está assinalada a "cor". Igualmente, nem sempre os registros de nascimento traziam a profissão exercida pelo pai no momento do registro. No caso das certidóes de nascimento, verifica-se que há correspondência entre a posição social dos pais e a "cor" com que a criança era registrada: filhas de "doutores", quando preenchida a rubrica "cor", eram sempre brancas.

O que mais podemos retirar desse conjunto de documentos? A maioria dos pais era casada. Dos documentos que trazem a nacionalidade do pai e da mãe, encontramos $75 \%$ de pais brasileiros. Filhas de imigrantes começavam a ingressar no magistério: aproximadamente $13 \%$ das requerentes brasileiras eram filhas de pais portugueses, italianos ou espanhóis. Apesar de não constar nos documentos a profissão de $60 \%$ dos pais, esta, quando assinalada, indica que a composição social das famílias de candidatas ao magistério não era das mais altas. Provavelmente, essas moças pertenciam à pequena classe média ou a estratos superiores dos trabalhadores manuais. Os percentuais são os seguintes: $8 \%$ declaram-se "doutores"; 3\%, comerciantes; $9 \%$, funcionários públicos; 7\%, militares (divididos em alferes, tenentes, capitães, majores, tenentes-coronéis e coronéis). Os demais são empregados no comércio, lavradores, jornalistas e topógrafos.

Quanto à cor desses candidatos, não estava preenchido o referido quesito em $71,75 \%$ das certidóes de nascimento. A cor "branca" constava em 26,6\% das certidóes. Dos candidatos registrados como brancos, $7 \%$ eram filhas de imigrantes. Já as cores "morena" e "parda" constavam em apenas $3,4 \%$ dos registros, um percentual muito pequeno, se comparado ao conjunto de registrados como brancos. Note-se que o cotejo desses dados com os de nacionalidade dos pais sugere mais do dobro de filhas de imigrantes em comparação com moças e rapazes escuros. 
Outra informação significativa é a origem socioeconômica das famílias desses candidatos não brancos, tal como registrada nos quesitos "profissão do pai" e "profissão da máe". Constatou-se que eles, os pais, ocupavam uma posição econômico-social estável. Eram brasileiros, pequenos funcionários públicos ou trabalhadores qualificados. Certamente, essa informação contribui para pôr em questão as condições de vida de pelo menos uma parcela da população negra carioca no período da Primeira República. Os dados sugerem a possibilidade de haver uma faixa de famílias entre a população não branca carioca que já havia conseguido ingressar na pequena classe média. Essa possível ascensão lhes daria condiçóes de manter os estudos das filhas ou de uma delas, e incentivar seu ingresso no magistério? São conjecturas. Só um estudo mais pormenorizado e localizado poderá responder satisfatoriamente a essa indagação.

Não obstante, havia um pequeno número de mães "agregadas" na casa do pai da criança, cujas filhas adquiriam certificados de perfilhação. Nesses casos, tinha-se, de maneira geral, este tipo de situação: o pai, em geral português, que vivia com a mãe, "mulher desimpedida". Ver, por exemplo, o requerimento de Luciana $^{2}$ de Oliveira, de 24 anos de idade, parda, cujo documento de identificação era uma "escritura de perfilhação". Na escritura, o declarante era João Francisco de Oliveira, português, casado, de 42 anos de idade. Constava como mãe Geralda Maria, solteira, de ocupação doméstica, natural do Espírito Santo, "agregada”, que vivia na residência do declarante.

Vale ressaltar que o grande número de documentos de identidade sem identificação da cor não permite conclusôes estatísticas. Não obstante, são suficientes, parece-me, para colocar a indagação das motivaçóes culturais que levavam à omissão desse dado.

A inexistência de registro do quesito "cor" em quase três quartos das certidóes de nascimento dos candidatos aos concursos pode ser explicada pela hierarquização racial construída no Brasil ainda antes da abolição do cativeiro. Assim, faz-se necessário pensar culturalmente esse problema. No Brasil,

[...] A noção de cor, herdada do período colonial, não designava, preferencialmente, matizes de pigmentação ou níveis diferentes de mestiçagem, mas buscava definir lugares sociais, nos quais etnia e condição estavam indissociavelmente ligadas. (MATTOS, 1998, p. 98; grifo da autora). 
Mattos (1998) apresenta inúmeras evidências de que a "cor" denotava um lugar social, não necessariamente designava matizes de pigmentação ou níveis diferentes de mestiçagem. O cativo, tendo obtido de alguma maneira sua alforria, imediatamente mudava de cor. Negro e preto eram a "cor" do cativo, era como se denominava o escravo. Ao adquirir status de homem livre, passava a ser registrado como pardo. Convém ressaltar que a classificação racial válida para uma região nem sempre o era para outras partes do País (FONSECA, 2007; SILVA, 1997).

Os atestados de vacinação e revacinação nem sempre traziam o registro da "cor". Eles foram localizados com mais frequência nos anos de 1920 e 1921, pois nem todos os requerimentos traziam anexados atestados de vacinaçáo. Ainda assim, o preenchimento do quesito "cor" dependeria da pessoa que estivesse "do outro lado da mesa", ou seja, atestados de vacinação de um mesmo requerente, dependendo do ano e da pessoa que os preencheu, poderiam apresentar informaçôes diferentes. Por exemplo: na segunda via (datada de 1918) da certidão de nascimento de Coaracy de Siqueira Amazonas ${ }^{3}$, nascida em Niterói, constava que, na certidão original, a sua cor era branca, segundo declaração de seu pai (funcionário público). No entanto, no atestado de vacinação, de 1920, sua cor é registrada como morena. No ano seguinte, em outro atestado de vacinação, sua cor consta como branca novamente. Já no atestado de vacinação de sua irmã, Nair Siqueira Amazonas, candidata ao concurso de 1920, consta morena como cor.

Esses exemplos mostram que preencher ou não o dado "cor" dependia dos interesses em questão e, principalmente, da condição ou das relaçóes sociais dos pais ou do jovem - caso dos atestados de vacinação. Dependendo desses fatores, a "cor" poderia ser clareada ou omitida.

Diferentemente das certidóes de nascimento, as de batismo não possuíam o campo "cor". No entanto, em duas delas havia referência à cor da pessoa no texto escrito pelo pároco: "No dia... pus os santos óleos em 'Fulano pardo' ou 'Fulano branco'". Ressalta-se que o pároco que escreveu essas declaraçóes de cor havia preenchido várias outras certidóes, anexas aos requerimentos, e em nenhuma constava a cor das crianças batizadas. Teria pretendido esse pároco, ao realizar tal registro em apenas duas certidóes de batismo - o que não era nem um pouco comum nos batistérios -, ressaltar o lugar social ocupado pelos pais dessas crianças? 
Observa-se, também, que a maioria das moças não brancas era oriunda de famílias brasileiras. Isto é, filhas de pai e mãe brasileiros, casados. Frequentemente, uma das avós não tinha sobrenome. Naqueles documentos que tinham registrados os nomes dos avós maternos e paternos, é comum encontrar, pelo menos, uma das avós sem o sobrenome. Seriam essas avós ex-cativas? No caso das camadas populares, pelas condiçóes de vida muito precárias, não havia preocupação com o registro formal. E, no caso de escravos que haviam sido alforriados ou comprado sua liberdade, muitos adotavam o sobrenome da família "proprietária" (FREYRE, 1951). Mattos (1998) se refere à preocupação de ex-cativos no Sudeste escravista em fazer uso dos símbolos de liberdade utilizados por seus congêneres ou pelos brancos, como casamento formal, registro dos filhos, etc.

No decorrer da pesquisa, encontrei na biblioteca do AGCRJ um livro que trazia os resultados do Censo de 1906. Em seu final, constava uma lista com 182 centenários cariocas. Segundo a apresentação, cidades importantes como Paris e Buenos Aires, quando realizaram os censos de suas populaçóes, procuraram resgatar os centenários que ali viviam. Com o Rio de Janeiro, "não podia ser diferente": o Censo de 1906 também apresenta uma síntese da vida dos centenários:

[...] de acordo com relatos de pessoas próximas a eles ou até mesmo do próprio recenseado, que apesar da idade avançada, possui recordaçóes e boa memória que permitem perceber a veracidade de sua idade através de uma relação entre a vida do recenseado e fatos históricos. (BRAZIL, 1907, p. 150).

Vários deles foram fotografados. Boa parte dessas imagens era de centenários de pele negra. Pelas fotografias e pequenas biografias, estabelecese uma relação entre "cor" e sobrenomes ou ausência de sobrenome e, no caso de alguns, o passado de escravidão. Também foi possível "cruzar" os sobrenomes dos avós dos candidatos aos concursos para professores adjuntos com os sobrenomes de centenários negros cujas fotografias constavam no livro. Assim, verificou-se que "Silva", "Jesus", "Santos", "Nascimento", "Conceição" e por exemplo, eram sobrenomes de pessoas negras, brasileiras ou africanas. Transcrevo, a seguir, os nomes de alguns desses centenários e respectivos resumos de suas biografias, tal como publicado nos resultados do Censo de 1906: 
Maria da Conceição: com 100 anos de idade, solteira, brasileira, analfabeta, recenseada na ladeira dos Guararapes no ${ }^{-10}$. Nasceu no Rio de Janeiro.

Benedicto dos Santos: com 100 anos de idade, solteiro, brasileiro, analfabeto, profissão ignorada, recenseado na rua Aqueduto no 65. Nasceu em Pernambuco e depois veio para o Rio de Janeiro, ficando algum tempo no município de Santa Maria Magdalena. Sempre trabalhou na lavoura.

Thereza de Jesus: com 120 anos de idade, solteira, africana, analfabeta, foi recenseada na rua Bom Jardim no 110 . Veio para o Brasil com 3 anos de idade.

Leopoldina Damascena: com 100 anos de idade, viúva, africana, analfabeta, recenseada na rua Dr. Rego Barros no 39, na Gamboa. Nasceu no Congo e chegou ao Rio de Janeiro com $\mathbf{5}$ anos de edade (sic) (grifos da autora).

Deolindo do Nascimento: com 100 anos de idade, solteiro, brasileiro, analfabeto, profissão ignorada, foi recenseado na rua Benedicto Hypolito no 65 .

Marcelino Jorge dos Santos: com 110 anos de idade, viúvo, africano, analfabeto, profissão ignorada, recenseado à rua Miguel Angelo, casa s/no (barracão). Veio para o Brasil com 5 anos de idade.

Fernando Felix do Espírito Santo: com 101 anos de idade, solteiro, brasileiro, analfabeto, operário, foi recenseado na rua da Alegria no 36. Nasceu na Bahia e veio para o Rio com 40 anos. Além de serviços domésticos, exercia, nas suas horas vagas, o ofício de sapateiro.

Domingas Rosa: com 110 anos de idade, solteira, africana, analfabeta, foi recenseada na rua Miguel Cervantes (casa) s/no (barracão).

Catharina Rosa: com 100 anos de idade, brasileira, analfabeta, foi recenseada na rua Souza Franco no $\mathbf{7 2}$. (BRAZIL, 1907). 
Contudo, vários desses centenários negros, africanos ou brasileiros tinham sobrenomes diferentes daqueles citados anteriormente. São exemplos: Lucrecia Borges; Domingas F. Vieira; Feliciana do Amaral; Aniceto Andrade; Manoel Valente da Silva, etc. Nomes e sobrenomes estão por merecer outra pesquisa e outra discussão. Um aspecto que merece ser assinalado é o eufemismo para o passado de escravidão. Segundo informações constantes no capítulo sobre os centenários no livro do Censo de 2006, o africano "veio" para o Brasil. Por exemplo: "Nasceu no Congo e 'chegou' ao Rio de Janeiro com cinco anos". Nada se escrevia sobre o passado de violência e opróbrio vivido pelo recenseado ou recenseada.

Cotejando os sobrenomes dos centenários com os sobrenomes dos avós dos candidatos constantes nos registros, foi possível encontrar a ascendência africana de um razoável número de professores que tiveram sua "cor" omitida nos documentos. A seguir, transcrevo alguns dados referentes aos avós dos candidatos e à "cor" deles, tal como registrado nos respectivos documentos de identificação. Com essa transcrição, tenho por objetivo facilitar ao leitor o entendimento do complexo processo de omissáo ou de registro da "cor" em tantas certidóes de nascimento (o nome do candidato será destacado em itálico). Só serão transcritos os dados de alguns daqueles em cujo documento de identificação não consta a "cor" ou que consta "cor branca". Ao cruzarmos os sobrenomes dos ascendentes, principalmente avós e mães, observamos que aumenta consideravelmente o número de professores negros no magistério do Rio de Janeiro. Dos $71 \%$ de candidatos que apresentaram certidóes de nascimento sem o registro da "cor", em 23,8\% não constava o nome dos avós. Avós sem sobrenome ou com sobrenomes como Jesus, Conceição, etc. eram da ordem de $14 \%$. Os avôs com sobrenome, junto com avós que não o tinham, representavam $9,5 \%$. A soma desses dois grupos perfaz um total de $23,5 \%$ de professores ou candidatos a professor com ascendência africana.

Antonio Correa Jorge da Cruz. Cor: Branca; Nascimento: 31/07/1899; Avós paternos: Domingos Homem Jorge da Cruz e Maria Ignacia de Jesus; não constam os avós maternos.

Benedicta da Conceição. Nascimento: 17/02/1889. Certidão de batismo: na filiação só há referência à figura materna: Rita da Conceição. 
Bernadina Vicente da Silva. Cor: não consta; Nascimento: 23/07/1891. Local: Capoeiras, Campo Grande/RJ. Filiação: João Vicente da Silva e Maria Francisca da Conceição. Avós paternos: Francisco da Silva e Maria Ignacia de Jesus.

Balduino Foster da Costa. Cor: não consta. Nascimento: 07/02/1891. Filiação: Thereza Maria de Jesus, o pai é ignorado. Avó materna: Maria Joaquina de Jesus.

Carmelita Bezerra Antunes. Cor: não consta. Nascimento: 05/04/1891. Local: Venda das Pedras, Itaboraí/RJ. Avó paterna: Bernarda Rosa da Conceição. Avó materna: Ceciliana Maria da Conceição.

Camillo Mallio. Cor: branca. Nascimento: 28/03/1902. Filiação: Antonio Mallio e Carolina "de tal" [é assim que o nome da mãe aparece na certidão]. Avós paternos: Vicente Mallio e Luiza Mallio. Avós maternos: Não constam.

Isaura dos Reis. Cor: não consta. Nascimento: 09/09/1889. Filiação: José Rufino dos Reis e Rita dos Santos. Avós: não constam.

Izaura Maria da Conceição. Cor: branca. Nascimento: 02/01/1896. Filiação: Rita Maria da Conceição. Não consta o nome do pai ou dos avós. [Certidão de nascimento e atestado de vacinação]. (BRAZIL, 1907).

Devido ao majoritário número de certidóes de nascimento sem o registro de "cor", tornou-se necessário buscar outras fontes que fornecessem mais dados sobre a origem racial do magistério do Distrito Federal. No caso, foram mapeadas fotografias de professores, acrescentando-se o cruzamento dos sobrenomes dos avós dos candidatos com os sobrenomes de centenários negros. As fotografias e a pesquisa dos sobrenomes indicaram um número muito maior de professores não brancos que aqueles que tiveram sua cor informada nas certidóes de nascimento $(3,4 \%)$. Também foi realizado um cruzamento dos sobrenomes dos avós dos candidatos com os sobrenomes de centenários negros fotografados no livro dos resultados do Censo de 1906. 
Dessa maneira, constatou-se expressiva coincidência entre os sobrenomes dos centenários e os sobrenomes dos candidatos e/ou de seus avós. É de se supor que sobrenomes frequentemente utilizados por pessoas negras, certamente ex-escravos, não seriam de uso comum aos "brancos da terra" (AZEVEDO, 1996), por seu menor valor social.

\section{O branqueamento do magistério do Distrito Federal}

A partir da junção dessas fontes, foi possível aferir que pelo menos $25 \%$ do magistério do ensino público do Distrito Federal eram composto por pessoas náo brancas. Esse percentual vale para a primeira década do século $\mathrm{XX}$ e vai diminuindo conforme vão passando os anos. De variadas formas, vai sendo produzido um processo de "branqueamento" do magistério. Isto é, os professores negros vão desaparecendo paulatinamente das escolas, dos cursos, das fotografias. Ao cabo de 20 anos, ao final do período da Primeira República, verifica-se seu quase total desaparecimento no ensino público do Distrito Federal.

Desde meados do século XIX, as elites brasileiras preocupavam-se com o futuro do País, dada a heterogeneidade racial e cultural da população. Essas elites eram influenciadas pelas teorias racistas, europeias e norte-americanas, então em voga, que postulavam uma hierarquia entre as raças e colocavam nos patamares mais baixos dessa hierarquia os povos amarelos e negros.

No final do século XIX, chegava-se a uma solução conciliatória: o Brasil deveria aspirar ao progresso "branqueando" sua população. Para tal, fazia-se necessário "importar" levas de trabalhadores europeus e, pensavam, ao final de algumas geraçóes, com a miscigenação, teríamos aqui uma nova raça branca, a "raça brasileira". Havendo-se chegado a um consenso, os debates sobre a "inferioridade racial" do brasileiro deixam de ter sentido. A "raça" como que desaparece das discussóes, e passa-se a colocar em evidência a importância de conformar a nação segundo padróes europeizantes, mais "modernos" e mais "civilizados". Daí porque o Censo de 1906 não traz o quesito "cor", e sim a origem nacional. Não havendo a preocupação em se discutir as "raças" e de igual maneira o recente passado da escravidão, explicase o apagamento das histórias ou das origens dos centenários africanos que "vieram" ou "chegaram" da África em tenra idade.

No meu entendimento, para que ocorresse esse "branqueamento" do 
magistério foi necessária a contribuição de dois conjuntos de fatores. Um deles, externo, por meio da reconfiguração de ideias que orientaram tanto os discursos oficiais quanto as práticas corretivas/curativas, que terminaram por atingir diretamente o grupo negro. $\mathrm{O}$ outro, interno, de racionalização do ensino público do Distrito Federal, que teve como um de seus resultados o "branqueamento" do corpo docente do Distrito Federal. De fato, já no final na década de 1910, esses dois conjuntos de fatores estavam quase perfeitamente imbricados: as ideias orientando as políticas educativas, e estas se conformando àquelas.

Qual terá sido a formação estratégica? O estabelecimento de um campo comum de observação/atuação que envolveu um modo particular de apreensão sobre um mesmo objeto (SAID, 1990). A reconfiguração de ideias, mencionada no parágrafo anterior, consolidou um conjunto de representaçóes negativas sobre a população negra e serviu como subsídio para orientar as políticas e as práticas de intervenção, fossem elas de modelagem cultural, no caso do ensino público, fossem curativas, no caso da saúde, ou repressivas, no caso da segurança pública.

A permanência e a consolidação dessas representações só foram possíveis porque inventadas, reiteradas e aludidas em experiências cotidianas. Mesmo que vagamente partilhada, porém inteligível em todas as formas de interlocuçóes, uma representação negativa da população negra e, em especial, das mulheres negras consolidou-se nas instituiçóes de ensino e em outras instituiçóes da sociedade brasileira.

O outro conjunto de fatores que tornou visível o progressivo afastamento das professoras negras do magistério público ocorreu a partir da racionalização do ensino. No que se refere à ocupação e desocupação de postos no interior da carreira do magistério, materializou-se um processo intencional, ainda que não explicitamente definido, de negação de espaço profissional a esse grupo racial.

Os primeiros anos da República foram protagonizados por intensos debates sobre como deveriam ser os caminhos da modernidade e do progresso para o País. Aos poucos, a escola passa a ser o espaço preconizado para a criação do povo brasileiro, uma vez que essas mesmas elites pensavam que até então não tínhamos um povo, e sim um aglomerado de populações. Foi paulatina a formatação da escola para assumir essa tarefa, principalmente no que se refere à cooptação de pessoal (no caso de professoras). O 
"branqueamento" atingiu os professores do ensino público que já exerciam a docência, assim como igualmente foi "branqueado" o alunado dos cursos de formação de professores. Inicia-se na década de 1920 e atinge seu ponto máximo quando a Escola Normal desaparece para dar lugar ao Instituto de Educação em 1932.

Retornando ao período em estudo, quais teriam sido, então, as condiçôes legais - da legislação educacional do município do Rio de Janeiro - que teriam permitido que moças e mulheres negras adentrassem no magistério em um período tão próximo da abolição do cativeiro? Ao contrário do que pensa o senso comum, nas últimas décadas do século XIX era pequeno o número de cativos no Rio de Janeiro. Silva (1997) informa que, às vésperas da Abolição, havia no Rio de Janeiro somente 7.488 escravos. Em 1890, para uma população de 522.651 indivíduos, 37,3\% eram pretos ou mulatos (BRAZIL, 1895).

Não é improvável que, entre a população de negros e mulatos, houvesse grandes diferenças quanto ao nível de instrução e de inserção profissional. Podemos citar como exemplo o professor Hemetério José dos Santos, professor do Colégio Pedro II, da Escola Normal e do Colégio Militar e autor de livros didáticos, ainda no Império. Também não é lícito supor que as professoras negras estavam em situação mais precária que suas congêneres brancas, por não possuírem o diploma da Escola Normal ou por ocuparem posiçóes temporárias ou subalternas no Ensino Primário público municipal. Para garantir tal afirmação, recorremos à legislação do ensino no Rio de Janeiro, desde os últimos anos do Império até os primeiros anos da década de 1930 .

\section{A formação do magistério: Escola Normal}

A Escola Normal do Rio de Janeiro, desde sua criação, em 1880, até 1916, apresentou algumas características que a tornavam uma escola profissionalizante aberta a pessoas de poucos recursos e/ou a professores já em exercício, mas sem estudos sistemáticos. Uma dessas características era seu horário flexível: durante vários anos, funcionou no período noturno e, posteriormente, em dois turnos.

Quando de sua criação, o curso da Escola Normal foi ministrado no período noturno, assim permanecendo até 1888. Já no ano de 1889, o 
curso funcionou somente no horário diurno - o Decreto no 10.060 , de 13 de outubro de 1888, determinou que se começassem os trabalhos escolares às 9 horas e terminassem às 16 horas. No ano seguinte, porém, voltou a ser um curso noturno.

Em 1897, os cursos da Escola Normal passaram a ser oferecidos em dois horários: diurno e noturno, sendo esse último exclusivamente para os normalistas adjuntos. $\mathrm{O}$ curso diurno funcionava das 9 às 14 horas, enquanto o noturno começava às 16 horas e terminava às 21 horas. No final desse ano, mantiveram-se os cursos nos horários diurno e noturno, mas já sem a exclusividade de ser o noturno para os normalistas adjuntos. Os dois turnos assim permaneceram até fevereiro de 1916; a partir daí, a Escola Normal passou a funcionar apenas no período diurno.

Em 1880, o curso da Escola Normal tinha a duração de três anos. Até 1928 , a duração do curso variou conforme as injunçóes políticoeducacionais.

\begin{tabular}{|r|l|}
\hline \multicolumn{2}{|c|}{ ESCOLA NORMAL DO RIO DE JANEIRO } \\
\hline Ano & \multicolumn{1}{|c|}{ Duração do Curso } \\
\hline 1880 & Três anos \\
1881 & Quatro anos \\
1888 & Três anos \\
1890 & Três anos (17 de maio) \\
1890 & Cinco anos (8 de novembro) \\
1893 & Quatro anos \\
1914 & Quatro anos \\
1919 & Cinco anos. Dois meses depois, o curso voltava a ter a duração \\
1922 & de quatro anos. \\
1928 & Quatro anos \\
& Cinco anos divididos em dois ciclos: o geral, de três anos, e outro, \\
1932 & Extinta a Escola Normal e criado o Instituto de Educação. O \\
& curso completo passou a ser de sete, oito ou nove anos, conforme \\
se destinasse à formaçáo de professores primários ou secundários. \\
\hline
\end{tabular}

Quadro 1: Escola Normal do Rio de Janeiro - duração do curso Fonte: SILVA (1936, p. 48). 
A outra condição era o tempo de duração do curso. Seguramente, era uma escola aberta às camadas mais modestas da população do Rio de Janeiro. De fato, até 1928, a aluna poderia levar mais tempo que o regulamentar para terminar seu curso e, principalmente, no caso das que já haviam ingressado no curso normal, poderia trabalhar como professora enquanto cursava a Escola Normal, o que, seguramente, facilitava a vida daquelas que precisavam - e parecia ser a maioria. Já no ano de 1904, o diretor da Escola, Manoel Bomfim, em discurso proferido às normalistas que concluíram o curso, referia-se à pobreza das professoras: “[...] a instrução popular, ensinar meninos [...] continua a ser função esquecida e humilde, para humildes e esquecidos".

Desde o início, as mulheres formaram o maior contingente entre o alunado. No livro Dos sucessos mais notáveis do anno lectivo de 1880 e das condiçóes do ensino na Escola Normal do Municipio da Corte (que faz parte do acervo do Instituto de Educação do Rio de Janeiro), primeiro relatório apresentado à Congregação da escola e redigido pelo professor Carlos Maximiano de Laet, era informado que se apresentaram como candidatos à matrícula na primeira série 288 indivíduos. Destes, seis não exibiram os documentos exigidos ${ }^{4}$, inscrevendo-se um total de 282 candidatos, sendo 105 do sexo masculino e 177 do sexo feminino. O mesmo relatório informa que, entre esses candidatos, havia um professor catedrático e três professoras catedráticas de instrução primária; um professor municipal e cinco professoras municipais; 15 adjuntos e 32 adjuntas efetivos; oito adjuntos e 20 adjuntas interinos. Nessa primeira turma do primeiro ano de funcionamento da Escola Normal, foram aproveitados todos os candidatos inscritos. Devido à grande quantidade de alunos, a Escola foi transferida das dependências do Colégio Pedro II (na atual Avenida Marechal Hermes) para dependências mais amplas, na Escola Politécnica (próximo à atual Praça da República).

Conforme afirmava o professor Carlos de Laet, os candidatos submetidos às provas - gramática, leitura, cálculo simples, etc. - não demonstraram possuir grandes conhecimentos. Contudo, as bancas de examinadores decidiram aprová-los na esperança de que os mais talentosos, após os estudos na Escola Normal, se tornassem bons mestres. Vale ressaltar que, mesmo na primeira turma, havia candidatos que já trabalhavam como professores. 
Os alunos da Escola Normal que fossem aprovados no primeiro e segundo anos estariam habilitados para as escolas de Primeiro Grau (escolas que ministravam as duas primeiras séries do Ensino Primário). Os que tivessem completado o curso estariam habilitados para as escolas de Segundo Grau (o restante do Curso Primário). Tanto uns como outros teriam preferência nos concursos para provimento das cadeiras vagas de instrução primária do município da Corte sobre qualquer outro que não tivesse o diploma de professor habilitado.

\section{Ingresso no magistério público}

Pertenciam ao magistério público no Rio de Janeiro, em 1890, 288 professores de letras (primários) e 224 professoras (BRAZIL, 1895). Professores particulares de letras eram 509 homens e 374 mulheres. Os diretores de estabelecimento de ensino eram: 52 homens e 69 mulheres (não havendo a indicação se públicos ou particulares).

Nas últimas décadas do século XIX e nas primeiras do século XX, a vida da imensa maioria da população do Rio de Janeiro era extremamente difícil. Os indicadores sociais eram sempre negativos em qualquer área: saúde, habitação, trabalho e condições de vida em geral (DAMÁZIO, 1992). Dadas essas condiçóes, explica-se que o exercício da docência devia exercer algum atrativo, pela segurança financeira que oferecia e por trazer algum retorno social àqueles que já detinham um mínimo de estudos e condições para aspirar a uma profissão "decente". Tanto que, em 1906 (BRAZIL, 1907), o magistério público no Distrito Federal havia aumentado. Nesse ano, o quadro docente era composto por 883 professores e 1.959 professoras.

A partir de 1890, o exercício do magistério público só era permitido a normalistas formados ou alunos da Escola Normal, aprovados em concurso. No entanto, caso não houvesse normalistas (alunos ou formados) em número suficiente, poderiam ser admitidas quaisquer pessoas (grifo nosso) que, mediante concurso, se mostrassem idôneas para o magistério. Contudo, a forma de organização do quadro de professores era bastante flexível, permitindo àqueles que necessitassem concluir seus estudos que o fizessem exercendo o magistério em funçóes hierarquicamente inferiores - caso dos adjuntos. Não obtendo vaga no serviço público, a professora normalista ainda poderia exercer o magistério, mesmo não tendo sido aproveitada no 
quadro regular do município - caso dos professores subvencionados. Estes recebiam da municipalidade uma pequena quantia para ministrar aulas em suas casas. Os professores que tivessem trabalhado cinco anos no ensino municipal obtinham a vitaliciedade.

Em 1893, foi promulgada a primeira Lei Municipal de Ensino. Essa lei, e as disposiçóes legais subsequentes, além de manter a divisão entre catedráticos e adjuntos, promoverá uma nova divisão: serão criadas as classes de professores urbanos e suburbanos. Os professores suburbanos eram aqueles que, aparentemente, mesmo tendo concluído a Escola Normal, não haviam obtido as melhores notas nos exames ou haviam demorado mais a concluir o curso. Havia outra forma de ingresso no magistério municipal: trabalhar gratuitamente em uma escola pública durante pelo menos um ano e obter carta de recomendação da diretora e, então, prestar concurso.

As professoras suburbanas, tanto as que já existiam como as que viessem a ser nomeadas, só poderiam ser transferidas para as escolas urbanas se viessem a merecer a gratificação adicional, na forma estabelecida na mesma lei. Contudo, não foram encontrados dispositivos legais que regulamentassem essa transferência, ficando a impressão da não-existência de fato dessa possibilidade.

Quais eram os critérios de ascensão no quadro do magistério? Na lei de 1893, por exemplo, os lugares de adjuntos efetivos seriam providos por diplomados pela Escola Normal, por merecimento, levando-se em conta, em primeiro lugar, o tempo de estágio. Entre estagiários com igual exercício ou, quando não houvesse estagiários, entre diplomados, seriam preferidos os de melhores notas.

Eram professores adjuntos estagiários os normalistas, diplomados ou não, maiores de 15 anos, que quisessem praticar no exercício do magistério. Não receberiam vencimentos, mas tinham preferência para a nomeação de adjuntos efetivos.

A referida lei também criava a figura dos adjuntos de segunda classe. Para esses cargos, seriam nomeados aqueles candidatos que, com mais de 15 anos de idade, tivessem, pelo menos, atestado de exame final do curso das escolas primárias, sendo sempre preferidos os de maiores habilitaçôes. Os candidatos com menor escolaridade só seriam nomeados depois de verificado não haver normalistas ou diplomados para essas nomeaçôes. 
Os adjuntos de segunda classe serviriam unicamente em escola suburbana, determinada na respectiva portaria de nomeação, como contratados, durante um ano, percebendo, a título de gratificação, pro labore, o mesmo que, como vencimentos, recebessem os adjuntos efetivos.

No primeiro e segundo casos (adjuntos estagiários e adjuntos de segunda classe), estavam muitas daquelas candidatas aos concursos de auxiliar de ensino. Aparentemente, apesar de as sucessivas normalizaçóes definirem a figura do adjunto como auxiliar do professor efetivo e seu substituto em caso de falta, na prática a professora adjunta terminava por assumir a direção de sala de aula. Uma economia para a municipalidade, pois a adjunta percebia um salário menor.

A organização do magistério, as formas de ingresso, a permanência e a ascensão continuaram as mesmas ao longo dos anos. Ainda que houvesse várias transformaçôes, adequaçóes e readequações dos quadros do magistério público municipal desde o final do Império até os últimos anos da década de 1920, estas não retiravam o caráter "popular", no sentido de estar o magistério público aberto a mulheres de poucos recursos, negras ou não. Em síntese, as mudanças eram mais de nomenclatura, de forma, que de conteúdo. Entretanto, perdura até 1928 a divisão professores urbanos (das escolas mais centrais) e suburbanos (Irajá, Santa Cruz, Jacarepaguá, Ilha do Governador, etc.).

\section{Os subúrbios}

A modernização da cidade no início do século XX, derrubando os cortiços e estalagens do centro da cidade para abrir as grandes avenidas (produzindo o movimento do "bota-abaixo"), empurrou para os subúrbios grande parte da população carioca, principalmente a população negra, que ali vivia. Em 1903, um decreto municipal estabeleceu que o território do Rio de Janeiro ficaria dividido em zona urbana e suburbana. Os distritos de Santa Cruz, Guaratiba, Campo Grande, Irajá, Jacarepaguá, Inhaúma e Engenho Novo eram considerados, a partir de então, zona suburbana.

O Censo de 1906 apresentava o crescimento de algumas regióes suburbanas no período de 1890 a 1906 (Quadro 2). Infelizmente, esse censo não considerou a distribuição racial dos recenseados, exceção feita aos centenários da cidade, e isso no caso dos que foram fotografados. Portanto, 
têm-se os números, mas não as características daqueles que se mudaram para os subúrbios. Contudo, é de se supor que o crescimento populacional acarretasse pressóes pela criação de mais escolas. Ademais, o transporte para essas regióes era difícil e caro, dificultando o deslocamento dos moradores para as regióes urbanas.

\begin{tabular}{|c|c|c|c|c|}
\hline \multirow{2}{*}{$\begin{array}{c}\text { FREGUESIA } \\
\text { SUBURBANA }\end{array}$} & \multicolumn{2}{|c|}{ POPULAÇÃO } & \multicolumn{2}{|c|}{ DIFERENÇA NO PERÍODO } \\
\hline & Em 1890 & Em 1906 & Absoluta & $\%$ \\
\hline Irajá & 13.130 & 27.410 & +14.280 & 108,76 \\
\hline Jacarepaguá & 16.070 & 17.265 & +1.195 & 7,44 \\
\hline Inhaúma & 17.448 & 68.557 & +51.109 & 292,92 \\
\hline Guaratiba & 12.654 & 17.928 & +5.274 & 41,68 \\
\hline Campo Grande & 15.950 & 31.248 & +15.298 & 95,91 \\
\hline Santa Cruz & 10.954 & 15.380 & $+4,426$ & 40,41 \\
\hline Ilha do Governador & 3.991 & 5.616 & +1.625 & 40,72 \\
\hline Ilha de Paquetá & 2.709 & 2.283 & 426 & $-15,73$ \\
\hline
\end{tabular}

Quadro 2: Número de habitantes das circunscrições civis - freguesias suburbanas Fonte: DAMÁZIO (1992, p. 27).

Paulatinamente, foi diminuindo a presença das docentes negras no Ensino Primário municipal. Os dados obtidos permitem inferir que a racionalização do ensino criou obstáculos cada vez maiores à presença dessas moças, tanto como professoras do ensino público municipal quanto como alunas da Escola Normal. Uma dessas medidas foi a extinção do curso normal noturno, em 1916, decisão tomada em nome de uma pretensa maior qualidade do curso diurno (o ensino noturno permitia às moças pobres trabalharem e estudarem ao mesmo tempo).

$\mathrm{O}$ acesso ao magistério público primário foi cada vez mais sendo restringido para aquelas moças que não tinham o fenótipo adequado. Como se a professora primária tivesse de ter a aparência física e social de uma nação que não existia na época nem existe hoje. Segundo Müller (1999, p. 145), “[...] os critérios dos exames médicos para ingresso à Escola Normal posteriormente Instituto de Educação - mais pareciam um delírio eugenista”.

A discriminação racial, dessa forma, não foi institucionalizada. Manteve-se no nível das relações, justificando hierarquias sociais e étnicas. Como assinala Schwarcz (1993, p. 247, grifo nosso): 
A raça se discute entre "pessoas" nos conflitos diários, na clínica médica, na personalidade das personagens dos romances científicos da época; a lei, entre "indivíduos", ou melhor, entre os reduzidos cidadãos dessa grande nação que participam das esferas políticas decisórias, dos debates externos e diplomáticos. Assim, se as conclusôes sobre a singularidade das espécies humanas, no Brasil, nunca constaram das leis ou dos documentos oficiais, conformaram um argumento frequente nos debates que levaram à elaboração dessas mesmas medidas.

No caso do magistério público do Distrito Federal, as reformas, leis e regulamentos foram criando balizas para impedir o ingresso nos quadros do magistério daquelas que náo tivessem a almejada aparência europeia. Literalmente, as barreiras legais criaram obstáculos quase intransponíveis para as moças negras, sem que houvesse, aparentemente, alguma manifestação formal, escrita, de resistência à cor da pele das professoras ou das candidatas à Escola Normal.

Como a discriminação racial não aparece em textos legais, memorandos, correspondência oficial, é necessário buscar o que pensavam aqueles que dirigiram a educação do Distrito Federal sobre a heterogeneidade racial do povo brasileiro. O texto citado a seguir é de Afrânio Peixoto e, segundo ele, fazia parte da compilação de suas notas de aula na Faculdade de Medicina do Rio de Janeiro em 1917. Afrânio Peixoto era médico. Foi professor e depois diretor, em 1914, da Escola Normal, e também Diretor da Instrução Pública. Esteve ligado à educação durante quase toda sua vida profissional. Seguramente, influenciou as reformas educacionais no Distrito Federal, principalmente quanto à elitização e à composição racial "ideal” do magistério municipal:

A decadência desses negros puros é sentida e demonstrada pela estatística. Se nos centros populosos parecem muito evidentes, é que acorrem a eles, desde a Abolição, empregados nas indústrias domésticas e servis, onde não têm a concorrência branca. Os descendentes deles, mestiçados com os brancos, são produto de passagem, disse, porque, além de vítimas preferidas pela tuberculose, (por má higiene, 
alcoolismo, sensualidade...) pela nevropatia, são branqueados nas sucessivas geraçóes a ponto de simularem raça branca. (PEIXOTO, 1938, p. 140141).

Grande parte da elite brasileira estava convencida de que a população do País não se constituía em um povo e pretendia que a escola pública criasse o povo brasileiro. Assim, graças aos ensinamentos ali ministrados, as novas geraçôes ficariam conscientes "de nossos vícios de raça" e estariam atentas para ter como "norte" e "ideal" a Europa, velho berço das mais importantes tradiçóes, e a América do Norte, centro dinâmico do progresso a ser imitado o mais rapidamente possível.

Nesse período, perseguia-se o objetivo de modificar a escola, racionalizá-la, modernizá-la e dar-lhe um caráter tal que lhe permitisse incutir nas novas geraçóes uma identidade nacional que contemplasse o espaço hierárquico ocupado por cada uma das três raças fundadoras da população brasileira: brancos no ápice, superiores, inteligentes, corajosos; índios, valentes, mas preguiçosos; e, finalmente, na posição mais inferior, negros, dotados de disposição para o trabalho físico e de "pouca inteligência".

Havia que conformar a instituição escolar de modo a que esta pudesse difundir o sentimento de nacionalidade e também formatar seus alunos com novos hábitos de trabalho e pensamento, para que estes, por sua vez, pudessem contribuir para a modernização do País. O "mestiçamento cultural", como dizia Peixoto (1938, p. 141), deveria ser combatido.

Com a escola reformada, esperava-se que desaparecessem as formas de sociabilidade da população negra que ainda persistiam (e que eram vistas como primitivas e atrasadas por essas elites): os batuques, o riso, a dança, a irreverência, a rebeldia, a capacidade de se reinventar e, por sua vez, de reinventar a cidade.

Nessa escola "moderna", qual seria o lugar daqueles que com sua "cor" e seu fenótipo afrontavam todos os planos de elitizar o magistério e toda a suposta cientificidade das teorias racistas? Não havia lugar para elas - não como professoras, talvez como alunas. É evidente que sua presença como professoras punha por terra todas as concepçóes da "inferioridade" intelectual e moral do negro. Devia incomodar profundamente a esses dirigentes da Instrução Pública a persistência dessas moças negras em seguir todos os passos 
que conduziam ao magistério. Apesar da pobreza e dos preconceitos, para alcançar o objetivo de serem professoras elas enfrentaram os anos difíceis do curso na Escola Normal, o concurso público e o exercício do magistério, sempre penoso e mal remunerado.

Essas moças não eram percebidas por aqueles, nem podiam sê-lo, dado o predomínio da ideologia do "branqueamento", como pessoas capazes de transmitir conhecimentos e os modelos de sentimento e conduta próprios da sociedade almejada por essas elites - uma sociedade branca, na qual negros e índios teriam desaparecido "miraculosamente". Não é casual que quase não se vejam alunas negras nas antigas fotografias do Instituto de Educação. Não aparecia mais a figura da "degeneração da raça" ou da "inferioridade de negros e mulatos", táo a gosto de Afrânio Peixoto e outros eugenistas. Essas representaçóes englobadoras, a partir daí, aparecem em outras entidades como "perfeição física" e "psicológica", critérios principais para ingresso nos estudos do magistério.

As consequências desse processo iniciado na Primeira República podem ser encontradas nos dias atuais. Se o magistério carioca e, possivelmente, o brasileiro passou décadas sendo reserva de mercado apenas dos professores brancos, ainda hoje professores negros são minoria em praticamente todos os graus de ensino, à exceção das primeiras séries do Ensino Fundamental (TEIXEIRA, 2006). É branco o magistério, como de resto são brancos praticamente todos os setores da elite brasileira.

\section{Notas}

1 Em 1906, o magistério carioca já era predominantemente feminino (MÜLLER, 1999).

2 Caixa Instrução Pública (Concursos) Letra "L" - Requerimentos de 1912 a 1919, AGCRJ.

3 Caixa Instrução Pública (Concursos Letra C) - Requerimentos de 1912 a 1919, AGCRJ.

4 Os requisitos para inscrição eram os seguintes: (a) certidão de idade ou documento equivalente, provando ter o "aspirante" 16 e a "aspirante" 15 anos de idade, pelo menos; (b) aprovação em exame de admissão, conforme programas estabelecidos em regulamentos; (c) atestados de 
distinta aptidão literária e de distinta moralidade, aquele passado pelos professores com quem estudou e este pelos párocos dos lugares em que residiu nos três últimos anos; (d) exame realizado por médico, para verificar estar o "aspirante" fisicamente hábil para o magistério; (e) autorização de pai, tutor, criador e do jus, se órfão; (f) compromisso por escrito de servir ao Ensino Primário do município da Corte pelo tempo de cinco anos sucessivos.

\section{REFERÊNCIAS}

AZEVEDO, Thales de. As elites de cor numa cidade brasileira: um estudo de ascensão social, classes sociais e grupos de prestígio. 2. ed. Salvador, BA: UFBA, 1996 [1955].

BOMFIM, Manoel. Discursos Proferidos na Solenidade da Entrega de Diplomas às Normalistas que Terminaram o seu Curso no Anno Escolar de 1903. Rio de Janeiro, Typ. do Instituto Profissional, 1904.

BRAZIL. Directoria Geral de Estatística. Recenseamento geral da Republica dos Estados Unidos do Brazil em 31 de dezembro de 1890:

Districto Federal (cidade do Rio de Janeiro), capital da Republica dos Estados Unidos do Brazil. Rio de Janeiro: Leuzinger, 1895.

BRAZIL, República dos Estados Unidos do. Recenseamento do Rio de Janeiro (Districto Federal): realizado em 20 de setembro de 1906. Rio de Janeiro: Oficina da Estatística, 1907.

CARRARA, Sérgio. Tributo a Vênus: a luta contra a sífilis no Brasil: da passagem do século aos anos 40. Rio de Janeiro: Fiocruz, 1996.

CUNHA, Olívia Maria Gomes da. Intenção e gesto: pessoa, cor e a produção cotidiana da (in)diferença no Rio de Janeiro, 1927-1942. Rio de Janeiro: Arquivo Nacional, 2002.

DAMÁZIO, Silvia F. Retrato social do Rio de Janeiro na virada do século. Rio de Janeiro: UFRJ, 1992.

FONSECA, Marcus Vinicius. Pretos, pardos, crioulos e cabras nas escolas mineiras do século XIX. 2007. 256f. Tese (Doutorado em Educação) Faculdade de Educação, Universidade de São Paulo, São Paulo. 
FREYRE, Gilberto. Sobrados e mucambos. Rio de Janeiro: J. Olympio, 1951.

MATTOS, Hebe Maria. Das cores do silêncio: os significados da liberdade no Sudeste escravista - Brasil séc. XIX. Rio de Janeiro: Nova Fronteira, 1998. (Coleção História do Brasil).

MÜLLER, Maria Lúcia Rodrigues. A cor da escola: imagens da Primeira República. Cuiabá: Entrelinhas/UFMT, 2008.

MÜLLER, Lúcia. As construtoras da nação: professoras primárias na Primeira República. Niterói: Intertexto, 1999.

PEIXOTO, Afrânio. Clima e saúde: introdução biogeográfica à civilização brasileira. Rio de Janeiro: Nacional, 1938. p. 140-141. (Biblioteca Pedagógica Brasiliana).

SAID, Edward. Orientalismo: o Oriente como invenção do Ocidente. São Paulo: Companhia das Letras, 1990.

SCHWARCZ, Lilia Moritz. Os institutos históricos e geográficos: guardiōes da história oficial In: . O espetáculo das raças: cientistas, instituiçóes e questão racial no Brasil, 1870-1930. São Paulo: Companhia das Letras, 1993. p. 99-133.

SILVA, Adriana Maria Paulo da. Processos de construção das práticas de escolarização em Pernambuco entre fins do século XVIII e primeira metade do século XIX. Recife: UFPE, 2007.

SILVA, Eduardo. Dom Obá II d'África, o príncipe do povo: vida, tempo e pensamento de um homem livre de cor. São Paulo: Companhia das Letras, 1997.

SILVA, Octacílio Augusto da. O ensino popular no Distrito Federal (Legislação). Rio de Janeiro: Typ. do Jornal do Commercio, 1936.

SKIDMORE, Thomas. Preto no branco: raça e nacionalidade no pensamento social brasileiro. Rio de Janeiro: Paz e Terra, 1976.

TEIXEIRA, Moema de Poli. A presença negra no magistério: aspectos quantitativos. In: OLIVEIRA, Iolanda de (Org.). Cor e magistério. Rio de Janeiro: Quartet; Niterói: UFF, 2006. p. 13-54. 


\section{The register of color in requirements for teacher hiring processes}

\section{Abstract}

This article presents data about the racial origin of candidates for jobs as teachers in Rio de Janeiro during the First Republic when the city was the national capital. It compares the registration of color on the candidates' birth certificates with other sources, and discusses the process of whitening of teachers in the capital at that time, based on discussions about a supposed inferiority of Brazil's black population, and the effect of these discussions on the rationalization of the career of teachers. It also discusses the forms of racial classification of Brazilians in this historic period. Skin color, once a simply biological attribute, took on a cultural, social and moral connotation in a wide set of demeaning qualifications. This process mainly took place with phenotypic blacks, or those with darker skin, who could not hide their racial origin.

Key words: Blacks - Brazil History - Old Republic, 1889-1930. Discrimination in education.

\section{El registro del color de la piel en requerimientos para los concursos de los profesores}

\section{Resumen}

En el presente artículo se presentan datos sobre el origen racial de los candidatos a los concursos de profesores adjuntos para el magisterio público de Rio de Janeiro - Brasil (antiguo Distrito Federal) en el período de la Primera República, donde se cruzan los registros de color en las partidas de nacimiento de los candidatos con otras fuentes. Se discute el proceso de "blanqueamiento" del magisterio del Distrito Federal, a partir de los debates sobre la supuesta inferioridad de la población negra brasileira y el efecto de esas discusiones en la racionalización de la carrera del profesorado. Se objetiva, también, las formas de clasificación racial de los brasileiros en ese período histórico. El color de la piel, atributo simplemente biológico, asume un contenido cultural, social y moral en un inmenso conjunto de calificativos que denotan inferioridad. Este proceso aconteció, principalmente, con las personas cuyo fenotipo era negro o de piel más oscura, que no podían de alguna forma disfrazar su origen racial.

Palabras clave: Negros-Brasil-República Vieja, 1889-1930. Discriminación en la educación. 


\section{Maria Lúcia Rodrigues Müller}

E-mail:mlrmuller@gmail.com

Recebido em: 19/2/2010

Aprovado em: 3/5/2010 